\title{
Lime-based Sacrificial Layers - Evaluation of a Traditional Conservation Method Applied in an Urban Environment
}

\author{
Farkas Pintér $^{1 *}$, Katharina Fuchs ${ }^{1}$ \\ ${ }^{1}$ University of Applied Arts Vienna, Institute of Conservation, Salzgries 14/4, A-1010 Vienna, Austria \\ * Corresponding author, e-mail: farkas.pinter@uni-ak.ac.at
}

Received: 20 January 2021, Accepted: 24 January 2021, Published online: 25 February 2021

\begin{abstract}
The use of modified lime slurry as a sacrificial layer to protect the original porous substrate has a long tradition in the practice of building and monument conservation in Austria. This paper presents the results of analyses performed on the Natural History Museum Vienna to get more insight into the long-term performance of this conservation method. Stone surfaces on the facade and roof area, covered with an acrylic tempered lime sacrificial layer and subsequently made water-repellent, were tested in situ and in the laboratory. Whilst coatings in the exposed zones were completely vanished in certain areas, the samples from the facade were in a good condition even after nearly twenty years of exposure. Hydrophobic activity could be verified up to a depth of five mm in the porous stone substrates. Despite the general good state of preservation of most surfaces, the existence of highly hydrophobic substrates will definitely restrict the implementation of any future sustainable conservation effort.
\end{abstract}

\section{Keywords}

sacrificial layer, water-repellent treatment, sustainable conservation, microscopy, monument

\section{Introduction}

A very significant example of the $19^{\text {th }}$ century architecture in Vienna is the twin complex of the Museum of Fine Arts and the Natural History Museum (NHM) on the Ringstraße designed by Karl Hasenauer and Gottfried Semper [1]. The construction of the NHM started in 1871 and lasted until 1889. The facade is mostly covered with various types of biocalcarenite/porous limestone and dense limestone types [2]. While at the pedestal different types of biocalcarenite from Oslip, Mannersdorf and Wöllersdorf (Burgenland and Lower Austria) were used [3], the lower part of the facade is mainly covered by Zogelsdorf (Lower Austria) biocalcarenite slabs [2, 3]. Contrary to the upper floors, where different porous limestone types from Austria and the neighboring countries were used, the more exposed attic and roof area was covered with dense and weatherproof karst limestone and a local conglomerate [2].

The previous conservation campaign started in the early 2000s, after almost 120 years of outdoor exposure, and was aimed at applying on the whole facade a surface coating matching the natural hue of the stone substrates and also protecting the subjacent surface. These coatings were produced simply, using lime putty and fine sand, but sometimes also pigments were added to the mixture; a technique that has been used in Austria since the Romanesque period [4-7].

Sacrificial layers ("slurries") based on a lime binder are reversible and periodically reproducible coatings, which, in the course of their own weathering, protect the underlying substrate (i.e., stone or mortar) [4-6, 8]. Although instructions of the correct application were described and discussed many times, problems such as poor processing were frequently observed [4].

Due to the improvement of water-repellent coatings during the second half of the $20^{\text {th }}$ century, new methods were elaborated and tested, which were combined with the above described traditional method including the modification of materials and cover coats [9-12]. The binder was tempered with acrylic dispersions and the finished surface subsequently treated with water-repellents. The long-term hydrophobic effect lengthened the time between required of conservation cycles and partly also reduced the pollution of the surfaces. During the 1980s this method was thought to be an efficient remedy. Additionally, hydrophobic treatment was often applied regardless, not only on architectural surfaces, but also on smaller monuments with different maintenance needs [4]. 
In the case of sacrificial layers another important factor of the conservation methodology is the maintenance. Unfortunately, it is often still excluded from the idea of long-lasting conservation cycles due to lack of understanding of its importance. No material can perform long-lasting life without continuous maintenance [4]. If examined regularly, necessary, and fast intervention can be done in order to keep the monument in a good condition including the further maintenance of the sacrificial layer. Damages occur more frequently on monuments that are either not maintained or maintenance is done without considering conservation aspects [4]. The conservation damages occur more frequently on monuments that are either not maintained or maintenance is done without considering conservation aspects [4]. The conservation activities on the facade of the NHM in Vienna started in 2000, and after the investigation of the stones' physical condition the main focus was laid on maintenance as well as protective and long-term conservation methods. First, gentle cleaning methods were used to remove weathering crusts from stone surfaces followed by the consolidation of soiling and fragile parts of the substrate. Secondly, conservation treatments and protective steps were employed, including the placement of lead covers on exposed horizontal areas. Finally, a sacrificial layer including a water-repellent treatment was applied. Between 2000 and 2009 each vertical section of the facades and the roof area were treated by different companies, but still with the same concept, application methods and materials [13]. Conservation activities focused on the application of sacrificial layers and subsequent water-repellent treatment of the coatings, while the idea behind the hydrophobic treatment was to extend the lifetime of the sacrificial layers [14].

Due to the importance of sacrificial layers in the conservation as practiced in Austria and Central Europe, an intensive research has been done recently in order to understand the performance as well as the long-term lasting of these protecting layers on different lime-based stone substrates. As part of this research, the present contribution is aimed to evaluate the composition and state of preservation of lime-based sacrificial layers at a well-documented and intensively treated Viennese historic monument.

\section{Sampling and analytical methods}

Due to the historical value and touristic importance of the NHM, only restricted sampling and in situ measurements were possible. Nevertheless, the sampling sites included different sections on the exposed northwest facade up to a height of approx. five meters and the roof area (Fig. 1) restored between 2001 and 2009 allowing the comparison of interventions carried out by different companies in different years (Table 1). In situ observations and measurements up to a height of five meters, including the determination and comparison of the color of different section's surfaces by using the NCS system (www.ncscolour. com) [15], were performed. A total of twenty-five samples (Table 1) including the sacrificial layers and the stone substrate have been documented and sampled. The hydrophobic properties of the surface [16], as well as the fresh broken surface of the substrate were estimated by applying a small water droplet with a pipette. Then, the surface of the sacrificial layers was documented by a portable digital microscope (DBPOWER Desktop Digital Mobile Microscope, DM). All samples were dried at $40^{\circ} \mathrm{C}$ overnight and after embedding them in epoxy resin, polished sections were prepared and analyzed by stereo-zoom (Leica S8AP0) and optical (Zeiss AXIOScope A1) microscopes, using raking (RL) and incident light (IL), respectively. Finally, the sections were coated with carbon before analysis by scanning electron microscope (Zeiss EVO15, acceleration voltage $20 \mathrm{kV}$ ), coupled with an energy dispersive X-ray spectrometer (EDS, Bruker Quantax XFlash, Bruker Esprit software). The estimation of the amount of air voids (given in area \%) was performed on the SEMEDS images. Additionally, the unprepared remnants of samples were also tested on their cross section by moistening their surfaces in order to determine the exact depth of penetration of the water-repellent treatment. Finally, the remaining level of hydrophobic activity on the top of the

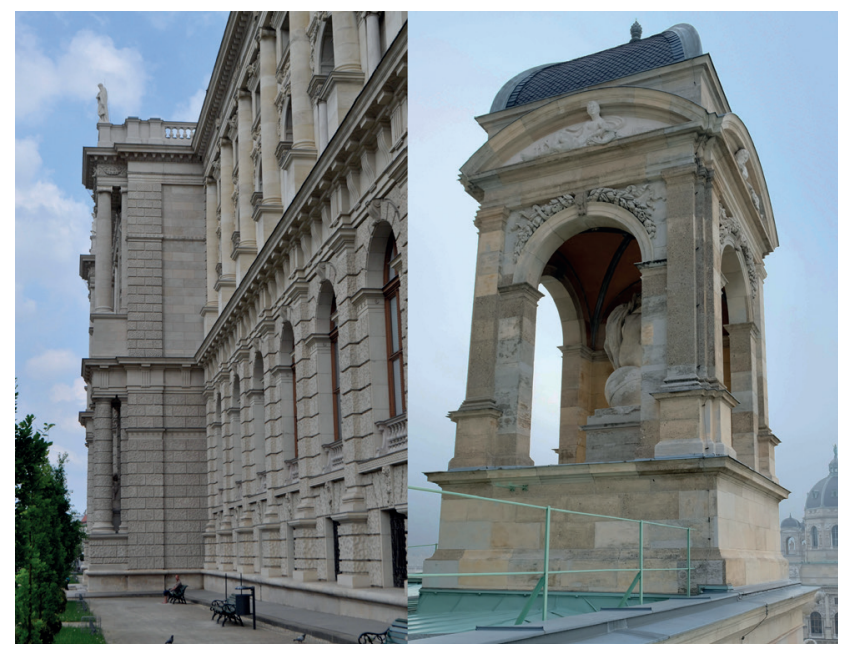

Fig. 1 The NW-facade (left) and part of the roof area (right) at the NHM 
Table 1 Sampling sites and main characteristics of the samples

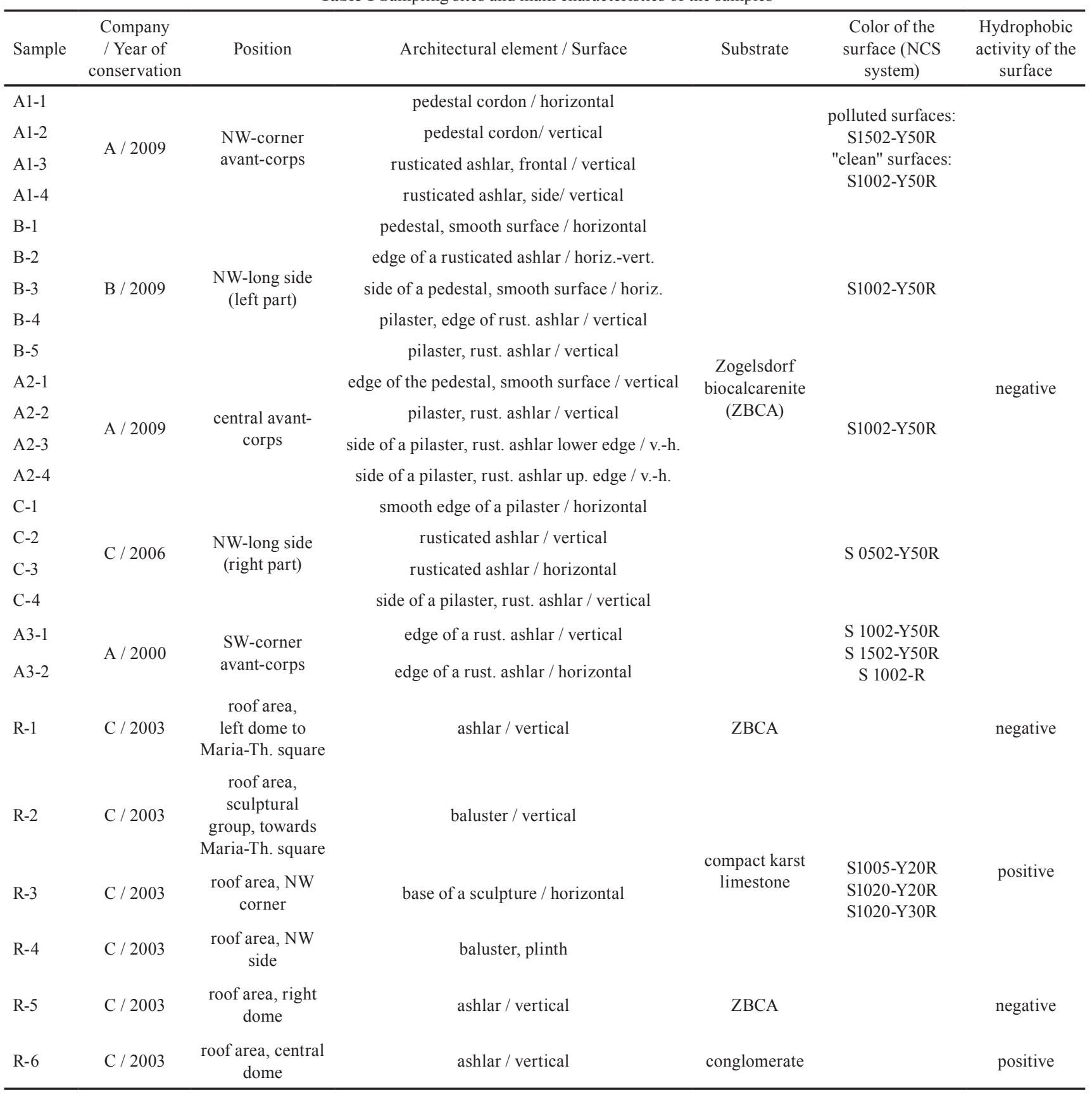

samples were tested and documented. In order to perform this, a small water droplet was placed on the horizontal surface of the coatings. If the water could soak into the surface (i.e., the hydrophobic activity has decomposed on the surface), the uppermost part (approx. $50 \mu \mathrm{m}$ ) of the coating was carefully removed by a scalpel, and the test has been repeated until the hydrophobic zone was found. Digital photographs were taken and the contact angle of the water droplet measured in order to estimate the hydrophobic activity in the samples [16].

\section{Results}

\subsection{Sacrificial layers on the northwest facade}

The conservation of the northwest facade was executed by three different companies (indicated by A, B and $\mathrm{C}$ in Tables 1 and 2) in five campaigns between 2000 and 2009. Table 1 and 2 show the results of the in situ observations and laboratory tests, respectively. The substrate on the entire surface investigated in this study is a porous Tertiary limestone (biocalcarenite) originating from the historical quarries near Zogelsdorf, Lower Austria [1]. 
In general, the surface coatings of the facade exhibit a good state of preservation and a homogenous appearance disregarding partial contamination with fine dust.

Based on the NCS charts the color of the coatings is offwhite and shows only slight variations (Table 1). Only the bright ochre hue of the sacrificial layers at the right part of the northwest long side (Samples C-1 to 4) differs from the rest of the northwest facade (S 0502-Y50R).

Despite the above mentioned color differences, the most noticeable structural feature of the sacrificial layers was the presence of varying amount (i.e., 5 to $50 \%$ ) of air voids. Fig. 2(a) shows an extreme example, where the partly altered surface of the coating, consisting of a binder embedding many air voids. Independently of the facade section and/or the company executed the work, different amount of air voids (mostly between 10 to $20 \%$ ) could be observed in all samples. The deposition of dust in these voids in sheltered surfaces was apparent in the case of earlier applications (samples A3-1 and 2). In situ water droplet tests performed on both vertical and horizontal surfaces indicated the absence of hydrophobic activity (i.e., flat or infiltrating water droplets) on the very top of the sacrificial layers in all sections. On the contrary, fresh broken surfaces showed contact angles $>90^{\circ}$ indicating their hydrophobicity (Fig. 2(b)).

Figs. 3(a)-(d) and Fig. 4(a)-(b) show the changes in water droplet contact angle on the top of the samples after carefully removing the top of the sacrificial layers. In all cases a distinct increase of the contact angles (90 to $\left.110^{\circ}\right)$ was observed, confirming the in situ tests performed at the facade and indicating that all sacrificial layers exhibit clear hydrophobicity far below their surfaces. Additionally, water droplet tests performed on the cross sections of the samples were used to determine the depth of penetration of the water-repellent agent. The measured depths of penetrations varied between 3 and $5 \mathrm{~mm}$ (Fig. 5, Table 2). Laboratory tests and further investigations by OM and SEM (Table 2, Figs. 6(a)-(d) and Figs. 7(a)-(d)) reveal more structural and compositional details. The yellowish color of the samples $\mathrm{C} 1$ to 4 was clearly due to the extensive use of yellow ochre pigments in the coatings (Fig. 7(c)). In almost all cases a good to excellent bond and no detachment between the stone substrate and (first) coatings were observed. The sacrificial layers mostly fill the surface porosity and roughness [14] of the biocalcarenite supporting the above described good contact surface. With the exception of the facade sections of the sample series B and C (Table 1), the sacrificial layers were predominantly applied in one layer.

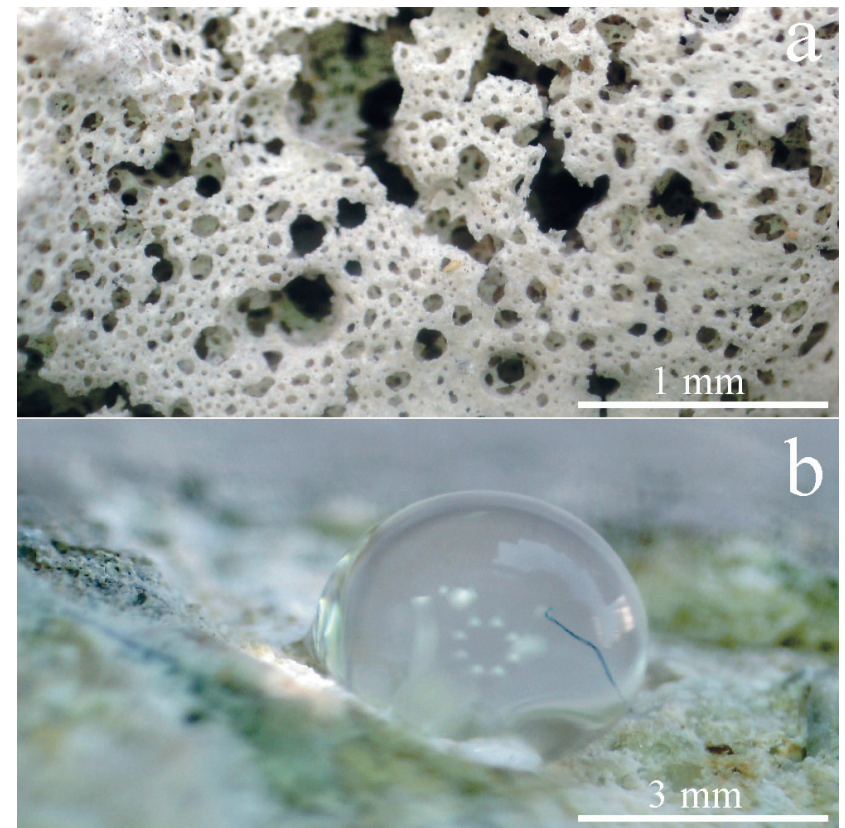

Fig. 2 Porous surface due to large amounts (approx. $50 \%$ ) of entrapped air voids in a coating on the facade, (a) Contact angle $>90^{\circ}$ indicates hydrophobic properties of the substrate, (b) DM

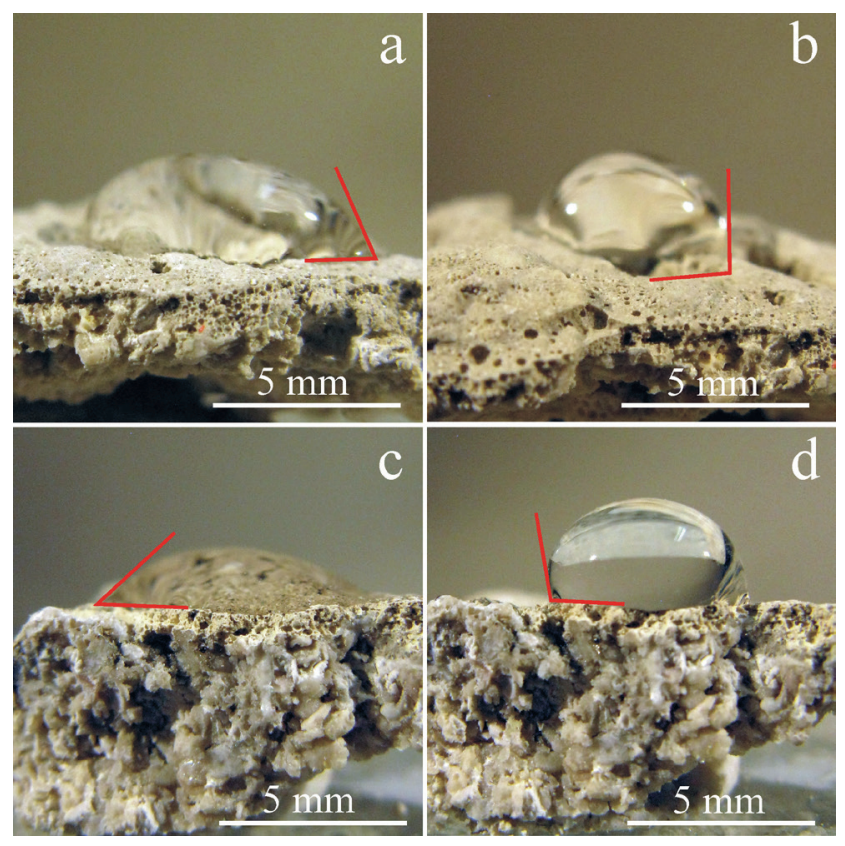

Fig. 3 Hydrophobic activity of sacrificial layers taken from the facade; (a) surface and (b) approx. $50 \mu \mathrm{m}$ below the surface (sample A2-3),

(c) surface and (d) approx. $50 \mu \mathrm{m}$ below the surface (sample C-1)

The thickness of single or multiple layers varied from 0.2 to $1.5 \mathrm{~mm}$, but samples from the sections $\mathrm{B}$ and $\mathrm{C}$ revealed larger thicknesses, where the single layers were also thicker compared to the other facade sections. Analyses on cross sections brought more insights into the distribution of air voids and their impact on the durability of the coat. 


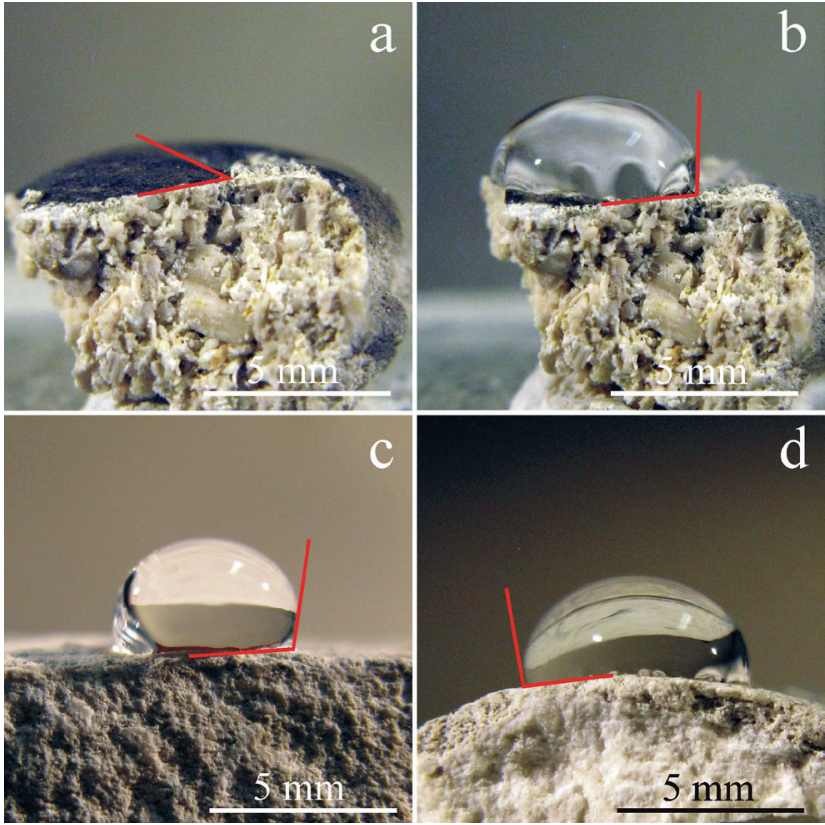

Fig. 4 Hydrophobic activity of sacrificial layers taken from the facade; (a) surface and (b) approx. $50 \mu \mathrm{m}$ below the surface (sample A3-1). Hydrophobic activity of sacrificial layers taken from the roof area (c) R-2 and (d) R-3

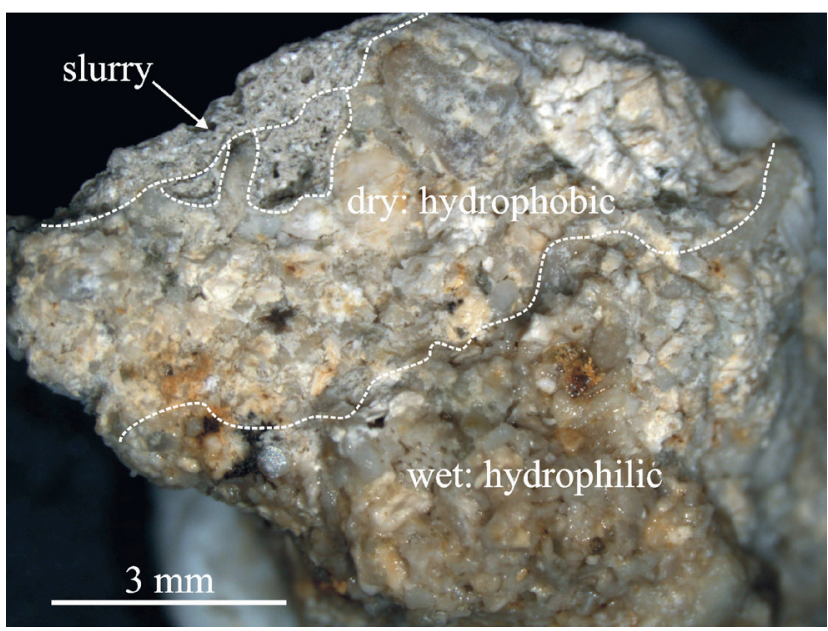

Fig. 5 Proof of depth of penetration of the water-repellent treatment on the broken surface (cross-section) of sample B-4. Dry zones indicate

hydrophobic, wet hydrophilic properties in the stone substrate

Although, the amount of air voids could be observed in situ even by naked eye, microscopic observations indicated partly large differences between samples taken from the same facade sections applied by the same company. Fig. 6 shows an example where the different amounts of air voids caused more intense alteration at same exposition time on vertical surfaces. While sample A1-3 contains (Fig. 6(a)) less air voids (approx. $8 \%$ ) and also more aggregate, the numerous (approx. $50 \%$ ) large pores in A1-4 (Fig. 6(b)) certainly contributed a faster degradation of the coating.
This assertion is also supported by the "open" shape of air voids. Similar phenomenon was observed on the samples from the southwest corner avant-corps (A3-1 and 2, Fig. 7(d)). Regarding the composition of the sacrificial layers, SEM-EDS analyses confirmed the type of binder and aggregate materials described in the (unpublished) reports by the conservators. Thus, sacrificial layers were prepared by using lime putty with limestone sand (i.e., crushed biocalcarenite) as an aggregate. Nevertheless, significant differences were observed in the grain-size distribution of the aggregates; while sacrificial layers should mostly contain aggregates $>63 \mu \mathrm{m}$ [14], many layers contained only fine limestone filler with a grain size $<50 \mu \mathrm{m}$. In two samples (B-2, Fig. 3 and Fig. 6(c)) small amounts of anhydrous cement phases (mainly $\mathrm{C}_{2} \mathrm{~S}$ and $\mathrm{C}_{3} \mathrm{~S}$ ) were also detected suggesting the use of white Portland cement as a hydraulic additive. Although neither investigated nor published, it is known from conservators' oral report that an acrylic additive (Primal SF 016, former Primal AC 33) was mixed into the slurries to enhance workability and adhesion during the application. High amounts of air voids observed in many coatings may also be an indirect evidence for the use of an acrylic additive and large amounts of water in the mixes. SEM-EDS measurements could not prove any traces of sulfate corrosion (i.e., formation of gypsum) or the presence of other damaging salts typical for polluted urban environments [17]. Despite the above mentioned dust deposits, traces of microbiological alteration (i.e. algae colonies, fungi, etc.) were not observed.

\subsection{Sacrificial layers on the roof area elements}

A large number of architectural elements on the roof area, such as domes, sculptures and balustrades, have been maintained and conserved by one company since 2003 (Table 1). Due to the differing stone materials and variable expositions significant differences were observed in the state of preservation of the coatings. Hence, depending on the substrate and the exposure, some areas (i.e., R-1 and 5) were intensively weathered, while others, such as the coatings on the compact limestone sculptures and balustrades, were less weathered and exhibited better state of preservation. Furthermore, the amount of air voids in the sacrificial layers was lesser compared to the samples from the facade and a more intense self-cleaning effect on the surfaces were observed.

The hydrophobic behavior of the roof area elements also exhibited differences compared to the samples from the facade. On top of sample R-1 the water-repellent treatment 
Table 2 Microstructure and water-repellent properties of the samples

\begin{tabular}{|c|c|c|c|c|c|c|}
\hline Sample & $\begin{array}{c}\text { Thickness / number of } \\
\text { layers }\end{array}$ & Adhesion to the substrate & $\begin{array}{c}\text { Entrapped air voids } \\
\text { (eav) }\end{array}$ & $\begin{array}{l}\text { Contact ang } \\
\text { on the present } \\
\text { surface }\end{array}$ & $\begin{array}{l}\text { le of water drop } \\
\text { approx. } 100 \mathrm{~mm} \\
\text { below the surface }\end{array}$ & $\begin{array}{c}\text { Depth of penetration } \\
\text { of the hydrophobic } \\
\text { treatment }\end{array}$ \\
\hline $\begin{array}{l}\text { A1-1 } \\
\text { A1-2 } \\
\text { A1-3 } \\
\text { A1-4 }\end{array}$ & $\begin{array}{c}0.2-1 \mathrm{~mm} / \\
\text { predominantly applied } \\
\text { in one layer }\end{array}$ & $\begin{array}{l}\text { good, no detachment was } \\
\text { observed; pore filling } \\
\text { contact }\end{array}$ & $\begin{array}{l}\text { in A1-2 and } 4 \text { many } \\
\text { eavs, otherwise not } \\
\text { significant }\end{array}$ & $40-75^{\circ}$ & $90-105^{\circ}$ & 3 to $5 \mathrm{~mm}$ \\
\hline B-1 & & & & & & \\
\hline $\begin{array}{l}\text { B-2 } \\
\text { B-3 } \\
\text { B-4 } \\
\text { B-5 }\end{array}$ & $\begin{array}{c}0.2-1.5 \mathrm{~mm} / \\
\text { predominantly applied } \\
\text { in more layers }\end{array}$ & $\begin{array}{c}\text { good, in B-2 moderate, no } \\
\text { detachment was observed; } \\
\text { pore filling contact }\end{array}$ & $\begin{array}{l}\text { except of B-5, very } \\
\text { little amount of air } \\
\text { voids }\end{array}$ & $50-70^{\circ}$ & $95-110^{\circ}$ & 3 to $4 \mathrm{~mm}$ \\
\hline $\begin{array}{l}\text { A2-1 } \\
\text { A2-2 } \\
\text { A2-3 } \\
\text { A2-4 }\end{array}$ & $\begin{array}{c}0.1-1.2 \mathrm{~mm} / \\
\text { predominantly applied } \\
\text { in one layer }\end{array}$ & $\begin{array}{c}\text { good, no detachment was } \\
\text { observed; pore filling } \\
\text { contact }\end{array}$ & $\begin{array}{l}\text { except of A2-4, little } \\
\text { amount of air voids }\end{array}$ & $30-70^{\circ}$ & $100-110^{\circ}$ & 3 to $4 \mathrm{~mm}$ \\
\hline $\begin{array}{l}\mathrm{C}-1 \\
\mathrm{C}-2 \\
\mathrm{C}-3 \\
\mathrm{C}-4\end{array}$ & $\begin{array}{c}0.2-1 \mathrm{~mm} / \\
\text { predominantly applied } \\
\text { in more layers }\end{array}$ & $\begin{array}{c}\text { good, no detachment was } \\
\text { observed; pore filling } \\
\text { contact }\end{array}$ & $\begin{array}{l}\text { in A1-2 and } 4 \text { many } \\
\text { eavs, otherwise not } \\
\text { significant }\end{array}$ & $50-70^{\circ}$ & $90-105^{\circ}$ & 3 to $5 \mathrm{~mm}$ \\
\hline $\begin{array}{l}\text { A3-1 } \\
\text { A3-2 }\end{array}$ & $\begin{array}{l}0.1-0.5 \mathrm{~mm} / \text { applied } \\
\text { in one layer }\end{array}$ & $\begin{array}{l}\text { good, no detachment was } \\
\text { observed; pore filling } \\
\text { contact }\end{array}$ & $\begin{array}{c}\text { in all layers many air } \\
\text { voids }\end{array}$ & $50-70^{\circ}$ & $95-110^{\circ}$ & 2 to $3 \mathrm{~mm}$ \\
\hline R-1 & $\begin{array}{c}0-0.6 \mathrm{~mm} / \text { strongly } \\
\text { weathered; applied in } \\
\text { one layer }\end{array}$ & $\begin{array}{l}\text { good (where existing); pore } \\
\text { filling contact }\end{array}$ & $\begin{array}{l}\text { no air voids; small } \\
\text { shrinkage cracks }\end{array}$ & $55^{\circ}$ & $100^{\circ}$ & $2 \mathrm{~mm}$ \\
\hline $\mathrm{R}-2$ & $\begin{array}{l}0.1-0.5 \mathrm{~mm} / \text { applied } \\
\text { in one layer }\end{array}$ & good & a few air voids & $105^{\circ}$ & $115^{\circ}$ & $\begin{array}{l}\text { ca. } 0.2 \mathrm{~mm} \text { (substrate } \\
\text { is not hydrophobic) }\end{array}$ \\
\hline $\mathrm{R}-3$ & $\begin{array}{l}0.5-1.5 \mathrm{~mm} / \text { applied } \\
\text { in three layers }\end{array}$ & good & small air voids & $100^{\circ}$ & $110^{\circ}$ & $5 \mathrm{~mm}$ \\
\hline $\mathrm{R}-4$ & $\begin{array}{l}0.8-1.0 \mathrm{~mm} / \text { applied } \\
\text { in three layers }\end{array}$ & good & a few, small air voids & $70^{\circ}$ & $110^{\circ}$ & $3 \mathrm{~mm}$ \\
\hline R-5 & $\begin{array}{c}0-0.4 \mathrm{~mm} / \text { strongly } \\
\text { weathered }\end{array}$ & moderate (where existing) & no air voids & $55^{\circ}$ & $50^{\circ}$ & - \\
\hline R-6 & $\begin{array}{l}0-0.4 \mathrm{~mm} / \text { applied in } \\
\text { three layers; weathered }\end{array}$ & good (where existing) & a few small air voids & $110^{\circ}$ & $85^{\circ}$ & only surface \\
\hline
\end{tabular}

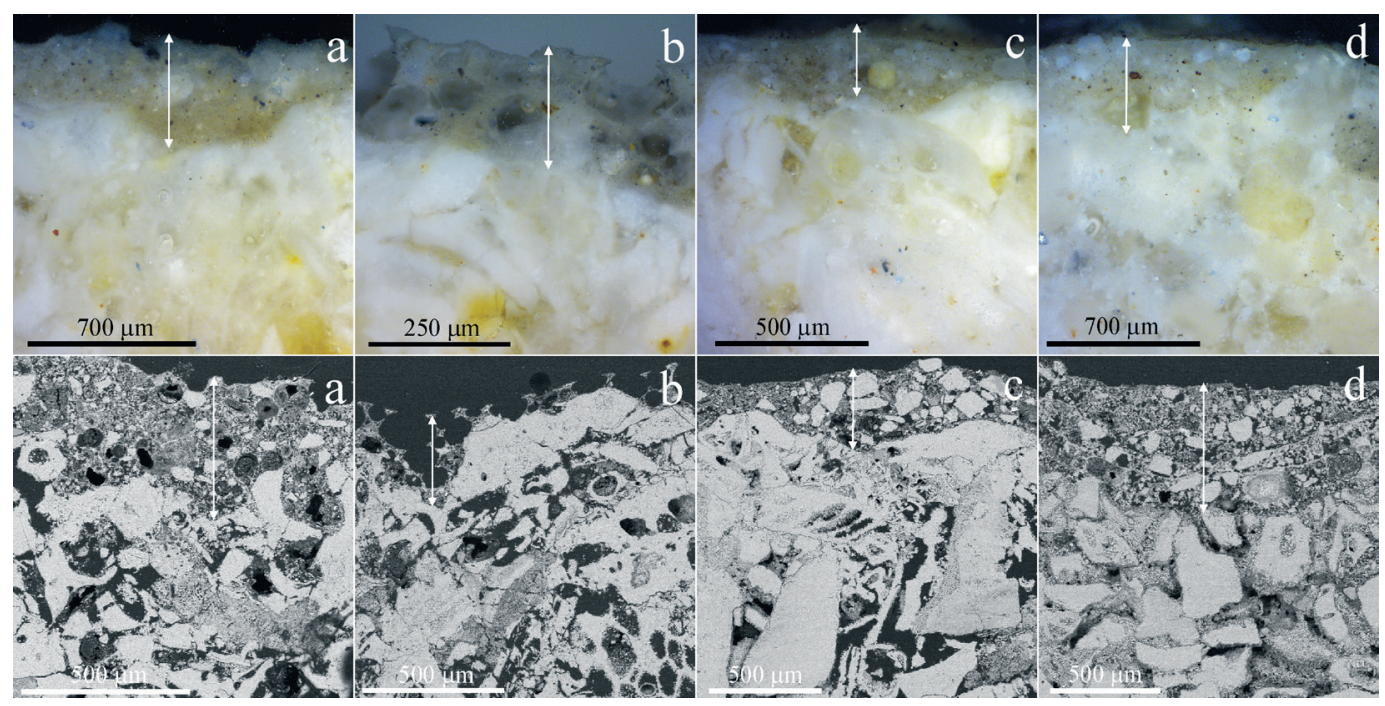

Fig. 6 Characteristic micrographs (upper line: OM, lower line: SEM-BSD) of sacrificial layers (double arrows) from the facade; a) A1-3, b) A1-4, c) B-2, d) B-4 
was absent, whereas underneath the coating (i.e. after removing it) up to a depth of approx. $2 \mathrm{~mm}$ the hydrophobic activity was clearly present. Large contact angles obtained on the surfaces of R-2 (Fig. 4(c) and Fig. 8), 3 and 4 (Fig. 4(d)) indicate hydrophobic properties that can be traced up to a depth of $5 \mathrm{~mm}$ (Table 2). In R-5 no hydrophobic properties were identified, and sample R-6 exhibited hydrophobicity only on its surface. Similarly to the in situ observations, laboratory investigations and tests were also characterized by larger differences compared to the rather consistent properties of the facade samples. Observations and measurements by optical and scanning electron microscopy (Fig. 9(a)-(d)) indicated variable coating thicknesses (Table 2), as well as variable composition of the layers. While only the samples R-1, 2 and 5 (Figs. 9(a)(c)) can be characterized as lime-based sacrificial layers with fine-grained limestone aggregate, the surface of the sample R-3 was covered by two layers of Portland hydraulic lime (lime putty with white Portland cement) and offwhite paint pigmented with titanium white. The later coat also showed higher amounts of silicon in the EDS spectrum confirming the use of a silicate-acrylic or silicone-based paint system. Furthermore, R-4 was also covered with a 0.5 to $1 \mathrm{~mm}$ thick coating made up of a Portland slag cement-air lime mix with crushed limestone as aggregate. In this case the surface was covered with a thin layer of lime-based paint pigmented with yellow ochre. It can be presumed, that all applied layers have acrylic additives. Finally, sample R-6 contained a thin layer $(50-100 \mu \mathrm{m})$ of lime-based sacrificial layer covered by two layers of limebased paints pigmented with yellow ochre giving the surface a yellowish hue (Fig. 9(d)).

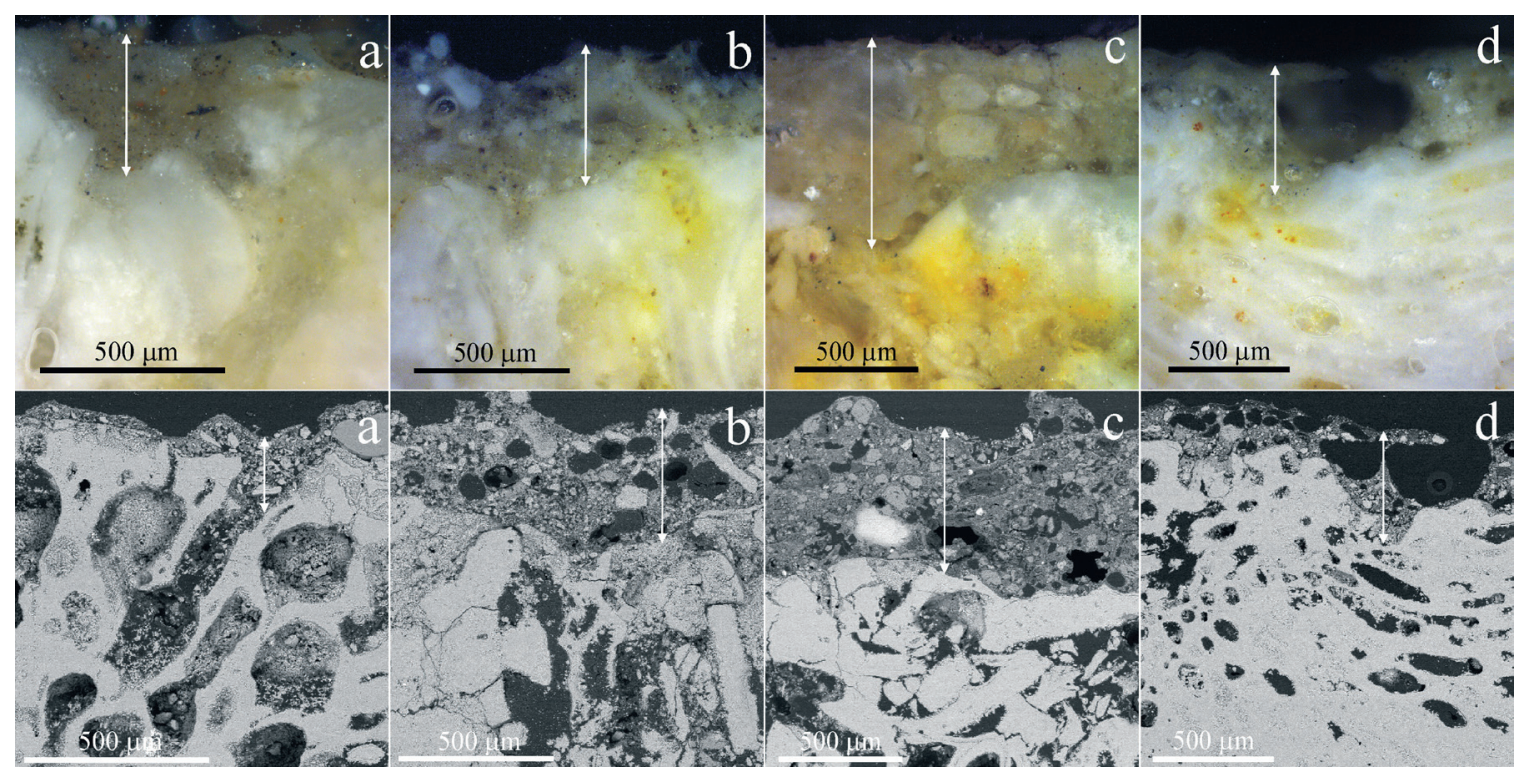

Fig. 7 Characteristic micrographs (upper line: OM, lower line: SEM-BSD) of sacrificial layers (double arrows) from the facade; a) A2-1, b) A2-4, c) $\mathrm{C}-3, \mathrm{~d}) \mathrm{A} 3-2$

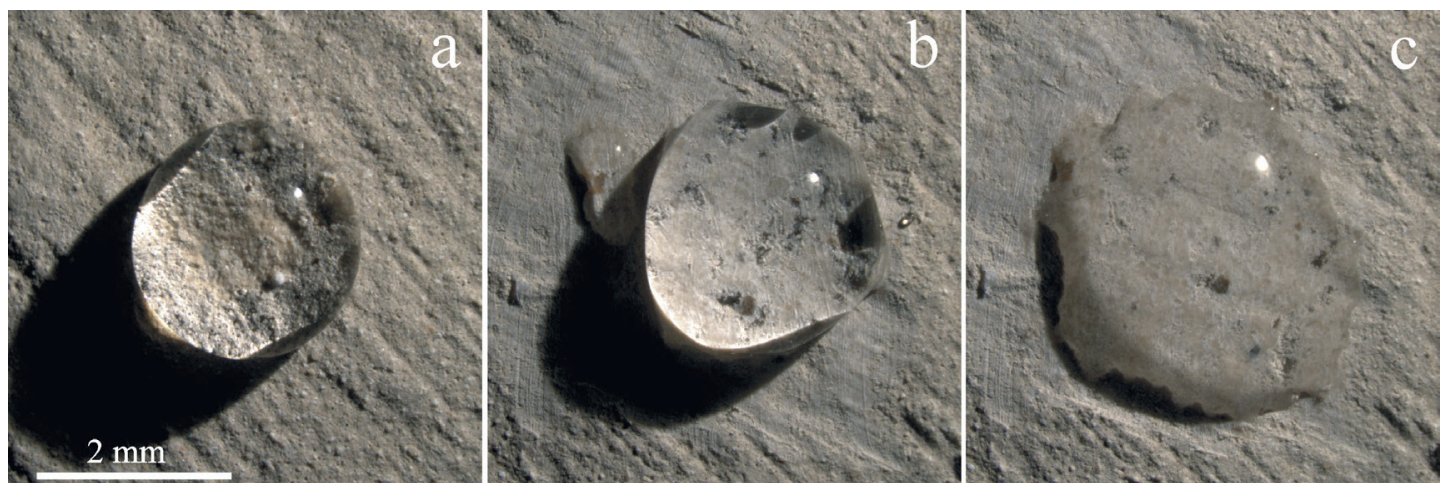

Fig. 8 Changes of contact angle (hydrophobic activity) by removing the sacrificial layer (R-2); a) surface (hydrophobic), b) approx. $50 \mu \mathrm{m}$ below the surface (slightly hydrophobic), c) on the surface of the substrate (non-hydrophobic) 


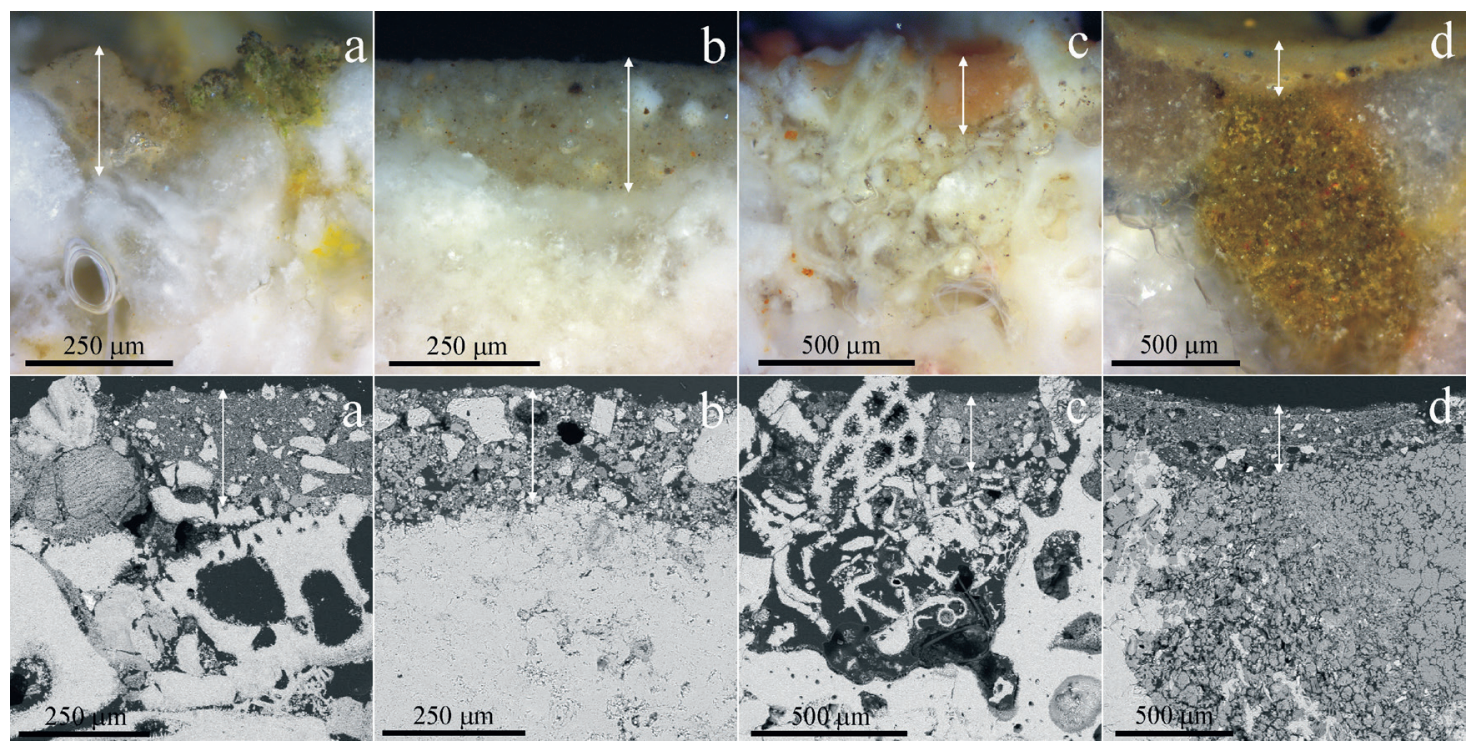

Fig. 9 Characteristic micrographs (upper line: OM, lower line: SEM-BSD) of sacrificial layers (double arrows) from the roof area; a) R-1, b) R-2,

c) R-5, d) R-6

\section{Discussion}

The in situ observations and laboratory investigations of twenty-five building stone samples covered with sacrificial layers from the northwest facade and the roof area of the NHM in Vienna enabled detailed insights into the composition, structure and behavior of sacrificial layers on historic monuments situated in urban environment.

Nevertheless, when interpreting the results care must be taken, especially in the case of the facade, because the limited amounts of sample provided only selective information on a large surface. Although a complete vertical section at the northwest facade was maintained by the same company using and applying the same products, we can only assume that the interpretation of results based on the observations and measurements taken on the lower zones of the facade are comparable to that of the higher levels. Therefore, the interpretation of the results on the northwest facade corresponds only to vertical surfaces (i.e., stone ashlars made of Zogelsdorf biocalcarenite) up to a height of approx. five metres and do not consider other stone substrates or facade elements (e.g., sculptures, outstanding cornices, etc.) which could not be sampled due to their position and thus have an unknown state of preservation.

Based on the first impressions the whole northwest facade showed a fairly uniform appearance. Only the right part of the northwest side (company $\mathrm{C}$ ) exhibited clear visual differences due to the excessive use of ochre pigments in the mixes giving that part of the facade a yellowish-beige hue.

While company A usually coated the surfaces in one layer, companies B and C frequently used multiple layers; therefore, the average thickness of their sacrificial layers were larger than those of company A. This could particularly be observed by naked eye in the section restored by company $\mathrm{C}$, where many surface details have been blurred due to the thick coatings. Although these features indicate a less accurate way of application, they do not necessarily have a negative impact on the appearance of the surface. An important feature was the presence of entrapped air voids in the sacrificial layers. In all sections, parts of the layers contained many air voids, but especially those applied by company A seemed to contain more of these macropores. The formation of air voids is not only connected to the mixing and preparation of sacrificial layers, but also to the amount of water and acrylate additive in the binder as could be confirmed by the authors' experiences. The fact that the oldest and thinnest coatings contained the largest amounts of air voids supports the assumption that too many entrapped air voids weaken the binder of the sacrificial layer and such surfaces are more affected by weathering. Also, the larger air voids contained more fine dust that had been captured due to the increased specific surface.

Apart from that, each sample taken from the facade was in a good state of preservation even after almost twenty years of exposure. Neither in situ observations, nor microscopic analyses indicated traces of detachment, saltaffected deterioration or weathering of biogenic origin even not in the case of the thinnest and thus most weathered sacrificial layers at the southwest corner avant-corps applied in 2000 .

The most significant and uniformly observed property at the northwest facade was the deep penetration of the water-repellent treatment that was used to extend the 
lifespan of the sacrificial layers [14]. In general, the treatment should only affect the sacrificial layer and not the (original) substrate [14]. The samples from the facade indicated, however, a very deep (i.e., up to $5 \mathrm{~mm}$ ) penetration depth measured from the present surface indicating that the upper few millimeters of the stone elements were also affected by the treatment. Even if the hydrophobicity was decomposed by weathering in the uppermost tenths of microns allowing a rather slow, but continuous weathering of the sacrificial layer, the water-repellent property in the deeper, protected zones of the original substrate will certainly remain for much longer time.

The complete absence of gypsum crusts and/or traces of sulfation horizons are a consequence of the continuous decrease of $\mathrm{SO}_{2}$ in the air due to strict environmental regulations in the EU since the 1990s [18]. Furthermore, the use of extensive water-repellent treatments could also hinder or inhibit the formation of sulfate products. Nevertheless, the lack of gypsum at the surface can certainly be interpreted as a consequence of the improving air quality in the last decades.

Unlike those from the facade, the samples taken from the roof area showed more variability in their properties. This was not only due to the different types of stone (i.e., mostly dense karst limestone and conglomerate) used at the exposed top of the building, but also of the more variable coatings. Both the exposition and type of coating influenced the state of preservation of the surfaces. Thus, dense limestone surfaces were either covered with acrylate-tempered lime slurry containing fine carbonate sand (R-2), or the surface/layer was additionally coated with a silicone-based paint (R-3). In samples R-4 and 6 no sacrificial layer was applied. The thick lime-cement coating in R-4 was most probably used as a putty to level the slightly damaged stone surface. High amounts of ochre pigments in the paint layers of R- 6 were deliberately added to imitate the brownish-yellow hue of the stone. Only the samples R-1 and 5 were coated with classical, in both cases pigmented, lime-based slurries.

Regarding the hydrophobic properties of the samples, significant differences were also detected. The depth of the water-repellent property changed between 2 and $5 \mathrm{~mm}$ in R-1, 3 and 4, in the case of R-2 and 6 only the surface revealed hydrophobicity. In R-5 no traces of hydrophobic property were detected. In the case of the latter sample in particular, it was clearly visible that the sacrificial layer has only been preserved in the micro depressions and pores of the stone surface. The strong weathering of the sacrificial layer on this roof segment is not just a consequence of exposition, but probably also because of the less penetration by the water-repellent treatment (i.e., only the surface of the sacrificial layer was impregnated).

The oldest sacrificial layers were applied almost two decades ago, but their state of preservation is comparable to that of later applications. Generally, it can be concluded that after ten to twenty years of exposure no damage due to the materials used and application methods can be observed. Each company has different application methods, therefore macro- and microscopic differences (color, structure, surface, etc.) between the applications are visible, and in some cases (e.g., company C) they can be interpreted as "characteristic fingerprints" of the executors. Since the functionality and aesthetic value of sacrificial layers and/or water-repellent coatings depend on the application, the most important factor determining the final quality depends mainly on the artisans and the external conditions (i.e., temperature, air humidity, solar radiation, etc.) while application. Nevertheless, despite these macroand microscopic differences one can assert that the sacrificial layers fulfil their function on the northwest facade by covering and protecting the substrate underneath and giving the surface a reasonably homogenous appearance.

Unlike the differences observed in the sacrificial layers, all companies applied the water-repellent treatment uniformly on the facade. The very deep level of penetration suggests that the silane/siloxane-based products were applied excessively. This is contrary to the idea of creating a thin hydrophobic impregnation in order to extend the durability of sacrificial layers and protract the maintenance cycles [14]. Therefore, the hydrophobic agents penetrating the porosity of the stones deeply cannot be interpreted as an optimal treatment. Due to the threeyear warranty period in Austria, it can be assumed that, companies applied too much water-repellent material for economic reasons in order to ensure a well-maintained appearance, even if problems or damage would occur underneath. This strategy may have been employed to avoid the need for future treatments [19].

Although the intense hydrophobic impregnation can be seen as positive, since it providing a longer service life for coatings, the penetration in the sub-surface zones of the substrate may cause difficulties in the future. Poorly applied water-repellent treatment combined with certain conditions, such as salt-laden structures and/or infiltration of water from behind the treated surface, frequently cause severe damages in the masonry [20]. 
However, in the case of the northwest facade of the NHM, the main problem lies elsewhere. Since the above mentioned failures were not observed even after almost twenty years of service life of some of the coatings, the difficulties related to the very deep penetration of the hydrophobic treatment are connected to the future maintenance of the stone facade. When discussing the current situation at the object, several questions rise especially about the re-treatability of these surfaces. Is a consecutive treatment with the same materials possible or would it be necessary to find a different product? The facade still appears well-maintained, but future problems cannot be determined at the present. Different degradation levels of the stone are observed throughout the facade, while no homogeneous degradation of the water-repellent treatment can be found (i.e. facade vs. roof area). Since the hydrophobicity cannot be removed from the stone even after the theoretical complete degradation of the sacrificial layer, the next conservation campaign has to face the problem of a water-repellent stone and/or coating surface. Consequently, a treatment with (pure) lime slurry cannot be executed. Thus, the next coating system has to possess hydrophobic properties or a very high amount of acrylic additives, otherwise the required adhesion and compatibility with the substrate cannot be guaranteed. The only materials currently available for replacing the sacrificial layers that would be capable of adhering to the hydrophobic stone are silicone resin-based. Finally, due to the above considerations the "predestination" of future treatments and maintenance may cause unexpected and unforeseeable degradation processes.

Due to the different degrees of degradation of the roof area samples and the slightly different coatings to cover the dense limestone sculptures, only a limited comparison is possible. Only two samples (R-1 and 5) had the same Zogelsdorf calacarenite substrate and lime-based coatings, but with completely different hydrophobic properties. Neither a deep penetration, nor a good state of preservation of the sacrificial layers could be observed. In regard to the durability this might be a negative effect, but, in accordance with the technical recommendations [14], the current state allows consecutive measures and a long-term maintenance of the surfaces in the future.

Finally, the results of this study point out the necessity of further investigations in order to find the best application methods for lime sacrificial layers with or without the addition of inorganic and organic additives and hydrophobic treatments. The application method of the water-repellent should be revised in order to avoid unnecessary deep penetration of the hydrophobic agent.

\section{Conclusions}

In the present study the performance of modified limebased sacrificial layers with additional water-repellent treatment applied on porous and dense limestone types at the northwest facade and roof area of the Natural History Museum Vienna were evaluated. Based on the results of the in situ observations completed with laboratory tests and microscopic analyses following conclusions can be made:

- in terms of thickness, color and general appearance sacrificial layers at the facade revealed more homogenous appearance compared to of the roof area;

- in the case of all samples good adhesion between the substrate and coatings, the lack of sulfate corrosion (i.e., formation of gypsum) and no secondary damages, e.g., due to freeze-thaw cycles or similar processes were observed;

- the differing, sometimes large amounts of entrapped air voids are a consequence of the acrylic additives to the lime slurry and the type of application;

- sacrificial layers containing more air voids may be exposed to faster degradation due to the high macroporosity of their surface;

- except for two examples in the roof area, all samples exhibited hydrophobic properties up to a depth of $5 \mathrm{~mm}$, indicating the intensive use of water-repellent agents during the previous conservation work;

- although impregnated surfaces may suggest an ideal surface treatment, in the case of a present object it may cause a problem during future conservation campaigns, because there is no (non-destructive) method which could remove the hydrophobicity from a porous medium;

- therefore, the possible use of coating/binder systems will be very limited in the future and the degradation potential of the surfaces remains hard to predict.

\section{Acknowledgements}

The authors thank Johann Nimmrichter for his support in sampling and providing information about the conservation activities at the object as well as Marija Milchin and Anthony Baragona for their critical comments and suggestions for improvement on the manuscript. 


\section{References}

[1] Seemann, R., Summesberger, H. "Wiener Steinwanderwege - Die Geologie der Großstadt" (Viennese stone hiking trails - The geology of the city), Brandstätter, Munich, Germany, 1998. (in German)

[2] Jovanović-Kruspel, S. "Das Naturhistorische Museum Wien. Architektur und Ausstattung - ein Tempel der Evolution" (The Natural History Museum Vienna. Architecture and facilities a temple of evolution), Doctoral Thesis, University Vienna, 2007. (in German)

[3] Von Rohatsch, A., Hodits, B., Nimmrichter, J. "Museum of Art History and Museum of Natural History in Vienna: Lithological composition - deterioration of the facades - restoration", Österreichische Ingenieur- und Architekten-Zeitschrift, 159(1-12), pp. 119-128, 2014.

[4] Koller, M., Nimmrichter, J., Paschinger, H., Richard, H. "Opferschichten in der Steinkonservierung - Theorie und Praxis" (Sacrificial layers for conservation of stone - theory and practice), In: 20 Jahre Steinkonservierung 1976-1996: Bilanz und Perspektiven, Mayer \& Comp., Vienna, Austria, 1997, pp. 143-150. (in German)

[5] Koller, M. "Denkmalpflege mit Opferschichten" (Monumental preservation with sacrificial layers), In: Österreichische Zeitschrift für Kunst und Denkmalpflege, XLIII, Verlag Berger, Vienna, Austria, 1989, pp. 48-53. (in German)

[6] Nimmrichter, J., Koller, M. "Opferschichten auf Kalksandstein und Kalkstein - Langzeitperspektiven einer präventiven Konservierungsmethode" (Sacrificial layers on porous and dense limestone - long-term perspectives of a preventive conservation method), In: Domstiftung Regensburg (ed.) Turm-Fassade-Portal, Colloquium zur Bauforschung, Kunstwissenschaft und Denkmalpflege an den Domen von Wien, Prag und Regensburg, Schnell \& Steiner, Regensburg, Germany, 2001, pp. 121-126. (in German)

[7] Nimmrichter, J. "Evaluierung von Konservierungsmaßnahmen an steinernen Denkmälern in Österreich" (Evaluation of conservation activities on stone monuments in Austria), In: Diekamp, A. (ed.) Naturwissenschaft und Denkmalpflege, Innsbruck University Press, Innsbruck, Austria, 2007, pp. 245-262. (in German)

[8] Ashurst, J. "Limewashing", In: Ashurst, J., Dimes, F. G. (eds.) Conservation of Buildings and Decorative Stone, Routledge, London, UK, 1991, pp. 229-230.

[9] Meyer, U. "Schlämmen für Natursteinmauerwerk - Anforderungen, Eigenschaften, Prüfverfahren, Applikation" (Slurries for natural stone masonry - requirements, properties, test methods, application), In: Wittmann, F. H. (ed.) Werkstoffwissenschaften und Bausanierung, Expert Verlag, Tübingen, Germany, 1993, pp. 10251035. (in German)

[10] Brandes, C. "Natursteinkonservierung durch Beschichtung. Untersuchungen zur Wirksamkeit und Dauerhaftigkeit von Anstrichsystemen auf Natursteinen" (Natural stone preservation by coating. Investigations on the effectiveness and durability of paint systems on natural stone), Doctoral Thesis, University of Hannover, 1995. (in German)
[11] Blöchl-Wirts, B. "Kalkbeschichtungen in der Denkmalpflege. Untersuchungen zur Substratabhängigkeit feuchtetechnischer Eigenschaften von Anstrichen und Schlämmen in Mehrschichtsystemen" (Lime coatings in the preservation of monuments. Investigations on the substrate dependence of the moisturizing properties of paints and slurries in multilayer systems), Doctoral Thesis, University of Hannover, 2000. (in German) https://doi.org/10.15488/5787

[12] Bermoser, I. "Kalkschlämme als Schutz- und Opferschichten auf Kalksandstein. Die Wiener Spinnerin am Kreuz. Restauriergeschichte und Evaluierung" (Lime slurry as a protective and sacrificial layer on porous limestone. The Viennese spinner on the cross. Restoration history and evaluation), Master Thesis, Institute of Conservation, University of Applied Arts Vienna, 2008. (in German)

[13] Wedenig, K. "Die Fassadenrestaurierung des Naturhistorischen Museums in Wien. Pilotprojekt/1. Bauabschnitt, Westlicher Eckrisalit (Bellariastraße)" (The facade restoration of the Natural History Museum in Vienna. Pilot project /1st construction phase, western avant-corps (Bellariastraße)), Natural History Museum Vienna, Vienna, Austria, Unpublished Report, 2000-2001. (in German)

[14] Ban, M., Beseler, S., Milchin, M., Nimmrichter, J., Rohatsch, A., Weber J. "Leitfaden. Schlämmen in Restaurierung und Denkmalpflege" (Guide. Slurries in conservation and care of monuments), BDA, Vienna, Austria, 2018.

[15] NCS "Natural Colour System ${ }^{\circledR}$, [online] Available at: www. ncscolour.com

[16] Wendler, E. "Einfache Prüfmethoden zur Zustandserfassung an Bauwerken - Bewertung und Abgrenzung sinnvoller Einsatzbereiche" (Simple test methods for the detection of condition of structures - evaluation and limitation of useful applications), In: Einfache, zerstörungsfreie Prüfverfahren, Arbeitshefte des Brandenburgischen Landesamt für Denkmalpflege und Archäologischen Landesmuseums, Workbook No. 26, Michael Imhof Verlag, Petersberg, Germany, 2011. pp. 10-17. (in German)

[17] Farkas, O., Siegesmund, S., Licha, T., Török, Á. "Geochemical and mineralogical composition of black weathering crusts on limestones from seven different European countries", Environmental Earth Sciences, 77, Article No. 211, 2018. https://doi.org/10.1007/s12665-018-7384-8

[18] EEA "Air quality in Europe - 2016 report", European Environment Agency, Copenhagen, Denmark, Report No. EEA 28/2016, 2016. https://doi.org/10.2800/413142

[19] Federal Chancellery of Austria "Bundesrecht konsolidiert: Allgemeines bürgerliches Gesetzbuch § 922" (Consolidated federal law: General Civil Code Section 922), Federal Chancellery of Austria, Vienna, Austria, 2002. (in German)

[20] Nimmrichter, J., Linke, R. "Evaluation of Hydrophobisation on Compact Limestone and Calcareous Tuff with Negative Result - Case Studies", In: Lukaszewicz, J. W., Niemcewicz, P. (eds.) Proceedings of the 11th International Congress on Deterioration and Conservation of Stone, Nicolaus Copernicus University Press, Toruń, Poland, 2008, pp. 1019-1025. 